\title{
Is the "Almost Perfect Scale" Almost Perfect? The Psychometric Properties of the Arabic Version of APS-R and Its Short Form
}

\author{
Ibrahim Kira1,2*, Hanaa Shuwiekh³, Kenneth Rice², Jeffrey Ashby² \\ ${ }^{1}$ Center for Cumulative Trauma Studies, Stone Mountain, GA, USA \\ ${ }^{2}$ The Center of Stress, Trauma and Resiliency, Georgia State University, Atlanta, GA, USA \\ ${ }^{3}$ Fayoum University, Fayoum, Egypt \\ Email:*kiraaref@aol.com
}

How to cite this paper: Kira, I., Shuwiekh, H., Rice, K., \& Ashby, J. (2018). Is the "Almost Perfect Scale" Almost Perfect? The Psychometric Properties of the Arabic Version of APS-R and Its Short Form. Psychology, 9, 1875-1897.

https://doi.org/10.4236/psych.2018.97109

Received: June 25, 2018

Accepted: July 28, 2018

Published: July 31, 2018

Copyright $\odot 2018$ by authors and Scientific Research Publishing Inc. This work is licensed under the Creative Commons Attribution International License (CC BY 4.0).

http://creativecommons.org/licenses/by/4.0/

\begin{abstract}
The goal was to evaluate the construct and predictive validity of the Arabic version of APS-R and check its invariance across genders and the English version supplied by one of the measure authors. We used its translated Arabic version, and measures of PTSD, complex PTSD (CTD), depression, and existential annihilation anxiety (AA), in a sample of 620 students from two Egyptian Universities. We conducted exploratory and confirmatory factor analysis (CFA) to test the APS-R's construct validity and zero-order correlation, curve estimation regression to test its predictive validity, and Multigroup invariance analysis to check its invariance between languages and genders. The three-factor model did not fit well which made its structural validity questionable. However, the model fitted well for each dimension separately. The results indicated that striving for standards and order, and self-discrepancy are distinct measures, and each has good construct and predictive validity. Order and standards predicted linearly and non-linearly lower PTSD, CTD (post-cumulative trauma disorders), depression, and AA. Self-discrepancy predicted linearly and non-linearly higher depression, PTSD, CTD, and AA. The non-linear models accounted for more variance than the linear models. While the measures were strongly invariant across genders, they were partially invariant across the English and Arabic samples.
\end{abstract}

\section{Keywords}

Perfectionism, The Arabic Version of APS-R, Striving to Order and Standards, Self-Discrepancy 


\section{Introduction}

Perfectionism is conceived as a personality trait and defined as "the striving for flawlessness" (Flett \& Hewitt, 2002: p. 5). There are numerous measures of the perfectionism construct (e.g., Hewitt \& Flett, 1991; Slaney, Rice, Mobley, Trippi, \& Ashby, 2001). Several factor-analytic studies have consistently distinguished between a striving-for-perfection, which has mainly adaptive aspects, and a self-discrepancy, which is primarily maladaptive (e.g., Stoeber \& Otto, 2006). These two aspects of perfectionism are conceptually and empirically different and incompatible to be included in one measure. Each aspect may have entirely different dynamics and disparate outcomes.

Self-discrepancy (Higgins, 1987) is an internal mostly negative dynamics. Discrepancies between the actual/own self-state and ought to self-state (i.e., representations of an individual's beliefs about duties, responsibilities or obligations, self-standards, and order), are predicted to be related to differences in levels of distress and self-satisfaction. Self-discrepancy between one's high standards and behavior involves constant and harsh self-scrutiny, self-blame, overly critical self-evaluation, and persistent concerns about others' criticism (e.g., Dunkley et al., 2003), and moral injury (Litz et al., 2009). A bulk of empirical findings supports a strong link between self-discrepancy and vulnerability to psychological disorders, for example, depression (e.g., Grzegorek, Slaney, Franze, \& Rice, 2004; Rice \& Slaney, 2002), anxiety (Saboonchi \& Lundh, 1997), obsessive-compulsive disorder (Moretz \& McKay, 2009), and PTSD (Egan, Hattaway, \& Kane, 2014). However, no studies have yet explored the potential relationship between self-discrepancy, existential anxiety, and comorbidity. Also, no studies have tested whether the relationships between self-discrepancy and these variables are linear or non-linear.

Self-discrepancy, as opposed to self-consistency or self-coherence, is ego dystonic dynamics that question authenticity and depletes self-resources and may be associated with elevated existential anxiety (i.e., annihilation anxiety [AA], (Kira, Templin, Lewandowski et al., 2012). Self-consistency or self-coherence, on the other hand, is seen as ego-syntonic and a meta-heuristic for comprehending the human condition and the ways of integrating diverse life experiences in an authentic self. On the other side, striving for standards and order is consistent with the underlying assumptions of the meaning-making framework (e.g., Baumeister \& Vohs, 2002; Park \& Folkman, 1997), striving for standards and order gives meaning to a person's perceived authentic identity and optimal life. Striving for perfection was found to be associated with lower anxiety and higher self-confidence and higher performance (e.g., Stoeber \& Otto, 2006; Stoeber \& Stoeber, 2009).

The Almost Perfect Scale-Revised (APS-R; Slaney, Rice, Mobley, Trippi, \& Ashby, 2001), is one of the established measures of perfectionism. APS-R has three subscales (standards, order, and discrepancy) to measure the two different components of perfectionism. 
The validity of the APS-R has been explored in several culturally diverse populations, and translated to various languages including Chinese, Asian, Indian, African American, and Turkish samples (e.g., Aydin; 2013; Yang et al., 2007; Mobley, Slaney, \& Rice, 2005; Slaney, Chadha, Mobley, \& Kennedy, 2000; Slaney, Mobley, Trippi, Ashby, \& Johnson, 1996; Ulu, 2007; Ulu, Tezer, \& Slaney, 2012; Wang, Puri, Slaney, Methikalam, \& Chadha, 2012; Wang, Slaney, \& Rice, 2007; Wang, Yuen, \& Slaney, 2009). Further, a short version of the scale that includes 8 of its items and represents standards and the discrepancy was tested and found to have similar characteristics (Rice, Richardson, \& Tueller, 2014). No studies previously explored it, or its short version of the Arabic culture or language.

Most of the previous studies on the structure of APS-R in different cultures utilized principal component factor analysis (PCA) in analyzing their data which is problematic. Scholars hotly debated the application of PCA against principal axis factoring PAF (e.g., Costello \& Osborne, 2005; Henson \& Roberts, 2006). PCA introduces more spurious common variance into solutions and assumes perfect measurement. The measure as it stands in previous validation in different cultures never subjected to rigorous analysis using PAF.

Further, research raise questions about the role of gender in mediating or moderating factor of the effects of perfectionism especially in specific domains such as eating, sports, math and science performance, and narcissism (e.g., Anshel, Kim, \& Henry, 2009; Gnilka, \& Novakovic, 2017; Shanmugam, \& Davies, 2015; Sherry, Gralnick, Hewitt, Sherry, \& Flett, 2014). There is a need to test the invariance of perfectionism structure across gender in The Arabic as well as across Arabic and English groups for APS-R and its short version.

The current article explores the psychometric properties of the Arabic version of APS-R. It uses the robust principal axis factoring PAF, to check the construct validity of the scale. It examines the compatibility of its two seemingly incompatible constructs: striving for self-standards and order and self-discrepancy. It tests an expanded predictive validity of the scores of its subscales. It expands on previous studies that explored the relationship between perfectionism subscales and vulnerability to PTSD, AA, and comorbidities, through testing linear and non-linear associations. Additionally, it tested the measurement invariance between genders. To follow the recommendation for testing the invariance of the translated measures with the original measure in its language (Ziegler, \& Bensch, 2013), we conducted Multigroup invariance analysis between the translated Arabic version (and its short form) and an English version provided by one of the scale developers.

Research Questions: The study research questions include the following:

Do the scores of the Arabic adapted version of the APS-R (and its short version) show adequate reliability, and construct and predictive validity of their interpretations? Specifically: Do the scores of the APS-R and its three subscales have an adequate alpha reliability (.70 or higher)? 
Are the three initial component structures the same in the Arabic version? Are the order and standards sub-scales different constructs than self-discrepancy? Does the interpretation of the three dimensions scores' show good construct validity?

Do the scores of the order and standard subscales predict lower psychopathology? Do the self-discrepancy subscale scores predict higher vulnerability to psychopathology (i.e., CTD, PTSD, depression and existential annihilation anxiety (AA) symptom scores)? Are these associations non-linear or strictly linear? The existence of non-linear relationships, may indicate the dynamics of cumulative effects?

Further, are the Arabic and English versions of the scale (and its short version) invariant across genders and groups?

Answering these questions may provide evidence of the predictive validity of the interpretation of the scores as well as of their invariance across genders and groups.

\section{Method}

Participants who took the Arabic version of the scale included 620 undergraduate students enrolled in Cairo University (Cairo, Egypt) and South Valley University (Qena, Egypt). The research team recruited the participants from the population of students taking undergraduate courses. We tried to represent all grades (freshmen, sophomores, juniors, and seniors) and different majors (humanities, nursing, and science) within the two different universities (Cairo and South Valley). Of the students invited, 620 agreed to participate in the study (90\%). Table 1 summarizes the characteristics of the sample. All questionnaires were administered individually to participants during winter and spring of 2014. Participation was voluntary. It took 45 - 60 minutes for each person to complete the questionnaire or the interview. The South Valley University IRB approved the research.

Participants in the USA sample (their data was provided by Professor Kenneth Rice who is one of the original authors of the scale) attended a large university (approximately 25,000 undergraduate students) in the southeastern portion of the USA. Participants were undergraduate college students $(\mathrm{N}=542,270$ women and 267 men, 5 with missing gender data). Ages ranged from 18 to $53, M=23.25$ $(\mathrm{SD}=5.08)$ (mostly young adults). The racial/ethnic distribution was $39.5 \%$ Black/African-American, 26.9\% White/European American, 18.1\% Asian, 8.2\% Latino/a, 4.1\% Multicultural/Mixed, 2.1\% reported “other," and .4\% Pacific Islander (5 subjects or $.9 \%$ had missing race/ethnicity data). The study was approved by the campus human subjects' research committee. The survey was administered online through Qualtrics, a web-based research survey tool. Because it was important to test the equivalence of the Arabic version to the original English version to establish future comparisons between the results, the American data that used the English version was used to test invariance. 
Table 1. Characteristics of participants of the Egyptian sample $(n=620)$.

\begin{tabular}{|c|c|c|c|}
\hline Variable & Sample distribution & Frequency & Percent (\%) \\
\hline \multirow{2}{*}{ Gender $\mathrm{x}$} & Male & 192 & 31 \\
\hline & Female & 428 & 69 \\
\hline \multirow{3}{*}{ Age } & $<20$ & 384 & 61.9 \\
\hline & $21-25$ & 216 & 34.8 \\
\hline & $\geq 26$ & 20 & 3.2 \\
\hline \multirow{4}{*}{ Academic standing } & Freshman & 184 & 29.7 \\
\hline & Sophomore & 292 & 47.1 \\
\hline & Junior & 76 & 12.3 \\
\hline & Senior & 68 & 10 \\
\hline \multirow{2}{*}{ Major } & Arts \& Humanities & 320 & 51.6 \\
\hline & Sciences & 300 & 48.4 \\
\hline \multirow{2}{*}{ University } & Cairo University & 322 & 51.9 \\
\hline & South Valley University & 298 & 48.1 \\
\hline \multirow{2}{*}{ Religion } & Muslim & 578 & 93.2 \\
\hline & Christian & 42 & 6.8 \\
\hline \multirow{3}{*}{ Marital Status } & Married & 50 & 8.1 \\
\hline & Single & 564 & 91 \\
\hline & Divorced & 6 & 1 \\
\hline \multirow{2}{*}{ Residence } & Village & 347 & 56 \\
\hline & Town & 273 & 44 \\
\hline
\end{tabular}

\subsection{Scientific Translation of the APS-R and Other Measures}

The research team translated the APS- $\mathrm{R}$ to Arabic according to the guidelines for translating psychological tests (International Test Commission, 2010). The committee of forward-translation consisted of three bilingual professionals who conducted the forward translation and two different bilingual professionals who contributed to the reverse translation. The research team in cooperation with the forward-translation committee compared the agreed-upon translated version.

Researchers have previously translated the other utilized measures following the same procedure. Furthermore, these measures have adequate reliability and validity in Arabic clients in previous studies, as will be briefly described in the measures section.

\subsection{Measures}

Almost Perfect Scale-Revised (APS-R; Slaney et al., 2001): The APS-R consists of 23 items rated on a 7 -point Likert scale $(1=$ strongly disagree, $7=$ strongly agree). The APS-R consists of three subscales: High Standards (7 items), Order (4 items), and Discrepancy (12 items). The psychometric properties of the 
APS- $R$ have been validated through a series of studies by Slaney and colleagues (see Mobley et al., 2005). Slaney et al. (2001) reported that the internal consistency estimates of the APS-R ranged from .85 to .92. Previous research found positive correlations of the APS-S with other measures of perfectionism which support its concurrent validity (Ashby \& Rice, 2002). We will present the reliability and validity estimates of the Arabic version of the APS-R in the results section. Additionally, we used the eight items short measure (APS-R-S), that was derived from the same items pool (Rice, Richardson, \& Tueller, 2014), that proved to have adequate validity and reliability in the English version. The short measure includes only standards and discrepancy subscales.

The Cumulative Trauma Scale CTS-S (short form) is a measure based on the development-based trauma framework (DBTF) (e.g., Kira, 2001; Kira, Ashby et al., 2013; Kira, Fawzi, \& Fawzi, 2013; Kira, Lewandowski et al., 2008; Kira et al., 2018; Kira, Lewandowski, Chiodo, \& Ibrahim, 2014; See also Kira, Shuwiekh, \& Bujoled-Bugeaud, 2017; Kira, Shuwiekh, Kucharska, Abu-Ras, \& Bujoled-Bugeaud, 2017). DBTF identifies and measures different dimensions of individual development that may be affected by stressors and traumatic stressors (i.e., attachment, personal, collective and role identities, and interdependence, as well as serious non-acute stressors). The CTS-S is a 32 -item instrument that measures cumulative stressors and traumas in terms of occurrence, frequency, type, and negative and positive appraisals. The scale is intended to be a comprehensive measure of cumulative stressors and traumas exposure. Cumulative non-traumatic stressors included the serious life changes associated with widowing/divorce and re-marrying, as well as the major life changes in forced relocations (e.g., uprootedness and immigration), and the experience of seemingly recurrent or unremitting hassles or chronic stressors. The scale includes, in addition to cumulative non-traumatic stressors ( 3 items), seven major trauma types: collective identity trauma ( 3 items), personal identity trauma (6 items), survival trauma (6 items), attachment trauma ( 2 items), secondary trauma ( 7 items), achievement traumas ( 2 items) and gender discrimination ( 2 items). Recently, the scale developers added three items that measure: perpetration trauma, community violence and birthing trauma (complicated birth) as optional items for interested researchers. Collective identity trauma includes trauma related to exposure to war and torture and discrimination based on race, ethnicity, or national origin. Personal identity trauma includes trauma related to sexual abuse, rape, incest, and being robbed. Attachment trauma includes abandonment by parents. Survival trauma includes car accidents, life-threatening illnesses, and natural disasters. Achievement or role identity trauma is intended to measure traumatic stressors related to achievement of life goals like success in school or business. Secondary trauma includes trauma related to having witnessed a traumatic event occurring to another individual or group and affecting social interdependence. Gender discrimination includes gender discrimination by parents (family) and gender discrimination by society and institutions. Gender discrimination items are worded to apply to both genders. In response to each item on the measure, 
participants are instructed to indicate their experience with a traumatic event on a 5 -point Likert-type scale ( $0=$ never; $4=$ many times). If a participant denotes that she/he has experienced the traumatic event, then he/she is asked to describe her/his appraisal of its effect on a 7-point Likert-type scale ( $1=$ extremely positive; 7 = extremely negative). CTS-S includes two general subscales for cumulative trauma dose: occurrence and frequency of experience, and two appraisal subscales: negative and positive appraisal of events. These four sub-scales may be also generated for each of the trauma types.

The CTS-S has shown adequate internal consistency ( $\alpha=.85$; Kira et al., 2008, Kira, Fawzi et al., 2013). Evidence of the instrument's predictive validity includes cumulative trauma significantly predicting post-traumatic stress disorder ( $\mathrm{r}$ $=.54, p<.001)$, cumulative trauma-related disorders $(\mathrm{r}=.24, p<.001)$, and poor health $(\mathrm{r}=.37, p<.001$; Kira et al., 2008). CTS-S has also shown divergent validity: It was significantly negatively correlated with sociocultural adjustment $(\mathrm{r}=-.25, p<.001)$ and futuristic orientation $(\mathrm{r}=-.37, p<.001)$. CTS-S has been used with a variety of clinical and community samples of adults and adolescents from numerous sociocultural groups and has been shown to possess adequate reliability (with an alpha ranging between .80 and .92), good construct validity (e.g., Kira et al., 2008, Kira, Lewandowski, Somers, Yoon, \& Chiodo, 2012; Kira, Smith, Lewandowski, \&Templin, 2010; Kira, Abou-Mediene, Ashby et al., 2012), and validity across different cultural and clinical groups, including American Indians, Mayans, Palestinians, Egyptians, refugees, and torture survivors from 32 countries (e.g., Kira, Ashby, Odenat, \& Lewandowski, 2013; Kira, Fawzi et al., 2013; Kira, Omidy, \& Ashby, 2014; Kira et al., 2010). The measure has been used in several studies as a comprehensive measure of stress and trauma (e.g., Gillespie \& Gates, 2013; Head, Singh, \& Bugg, 2012; Millender, 2013; Omidy, 2012) and has been found to have good reliability and predictive validity. It have been translated to different languages including Arabic, Spanish, Polish, and Nigerian and proved to have good psychometrics properties in these languages. Test-retest using an independent sample of 35 males with four weeks interval yielded excellent stability coefficients (.995 for cumulative trauma frequency, and .997 for cumulative trauma appraisal). The alpha for the main scale of occurrence was .88 with Egyptian data and .91 in the Polish data.

The Clinician-Administered PTSD Scale (CAPS-2) is a structured clinical interview that assesses 17 symptoms rated regarding frequency and severity of symptoms on a 5-point scale. The CAPS has demonstrated high reliability, with a range of .92 - .99, and good convergent and discriminant validity (Weathers, Keane, \& Davidson, 2001). The measure contains two subscales: frequency and intensity. Elhai et al. (2006) found that the two subscales were highly intercorrelated (from .86 to .93) and were not differentially related to the summed PTSD scores or PTSD diagnoses. Also, Betemps, Smith, Baker, and Rounds-Kugler (2003) discovered that the frequency format associated with greater reliability and item discrimination than the intensity format. The current study utilized the fre- 
quency subscale. Psychiatric research widely used the frequency format. Trained, fully licensed psychologists administered CAPS-2 through one-on-one interviews with all participants. The measure had an alpha of .91 with the current data.

The Center for Epidemiologic Studies Depression Measure (CES-D; Radloff, 1977 ) is a 20-item scale wherein each item is assessed on a 4-point scale and reflects the frequency with which each symptom is experienced $(0=$ none of the time, 3 = all of the time). Research reported adequate reliability and validity for the CES-D. A cutoff score of 16 is commonly used for the CES-D to indicate a need for further assessment of the presence of major depressive disorder (Radloff, 1977). Different studies found high reliability (ranging from .85 to .92) for the CES-D among various age, sex, geographic, and racial-ethnic subgroups. Validation studies have found that the CES-D has good convergent and discriminant validity and high sensitivity and specificity. Its internal consistency reliability (Cronbach's alpha) in the present study was .89.

Cumulative Trauma-related Disorders Measure (CTD; Complex PTSD; Kira, Templin, Lewandowski, Ashby et al., 2012; Kira, 2010). The measure's authors developed the 16-item scale on five community and clinical samples of adults, adolescent Iraqi refugees, Arab Americans, and African Americans. It is an index measure that covers 13 different symptoms, A score of 0 indicates that the symptom is not applicable, $1=$ not sure, $2=$ somewhat present, $3=$ present and 4 = very much present. Exploratory and confirmatory factor analysis Found four comorbidity clusters: executive function and control deficits, suicidality, psychosis/ dissociation, and depression/anxiety/somatization clusters. The scale has good reliability (ranging from .85 and .98 in five different studies). The test-retest reliability in a 6-week interval was .90 . The measure has good convergent, divergent, and predictive validity. Various types of trauma and cumulative trauma, in general, accounted for significant variance as predictors of CTD symptoms. The scale had an alpha coefficient of .86 in this study.

Annihilation (Existential) Anxiety Scale (EAA) (Kira, Templin, Lewandowski, Ramaswamy, Bulent, Mohanesh et al., 2012; Kira, Templin, Lewandowski, \& Shuwiekh, 2018). The scale developers assume that there are at least three primary sources of the emergence of self-annihilation threats: threats to personal identity, collective identity, and threats from severe societal structural inequalities. Three items that represent the three components were used, e.g., "Because of what has happened to me personally or is happening to me personally, I sometimes worry that I just lose my sense of self (I worry that I will cease to exist as a person)." The answer was structured on a 5-point Likert-scale ( $5=$ strongly agree, 4 = agree, 3 = not sure, $2=$ disagree, $1=$ strongly disagree). A score of 10 or higher indicates the presence of at least one related concern. Researchers used the scale previously for Iraqi refugees in Michigan, on three samples of Palestinian adults and adolescents and of mental health clients $(N=399)$. In the initial validation study and subsequent studies, its alpha reliability ranged from .90 - .95, and its convergent, discriminant and predictive validity were adequate. The scale's alpha coefficient was .78 in the current data. 


\subsection{Statistical Analyses}

The data were analyzed utilizing IBM-SPSS 22 and Amos 22 software. We split the sample $(\mathrm{N}=310$, for each) using SPSS commands (e.g., select a random sample of the cases). We conducted exploratory (on the first sub-sample) and confirmatory factor analysis (on the second sub-sample). Because order and standards may not be independent, we conducted an oblique rotation. We used the scree test (Cattell, 1966) and parallel analysis (O’Connor, 2000) to help determine the number of factors. Confirmatory factor analysis was conducted on the resulted in three factors and separately for each dimension (striving to standards and order, and discrepancy) to see which one best fit the data. Following Byrne's (2012) recommendations, the criteria for good model fit were a nonsignificant $\left(\chi^{2}\right),\left(\chi^{2} /\right.$ d.f. $\left.>2\right)$, comparative fit index $(\mathrm{CFI})$ values $>.90$, and root-mean-square error of approximation (RMSEA) values $<.06$. We investigated the reliability of the scale with the Cronbach's alpha. To test its predictive validity, we conducted a zero-order correlation and a curve estimation regression to explore the linear and non-linear relationships between the three components of perfectionism and PTSD, CTD, depression, and existential anxiety (AA).

Additionally, to assess the measurement invariance across genders and Arabic and English versions, nested model comparisons from these multiple groups' analyses were made using the Satorra-Bentler scaled chi-square. Four nested models were tested sequentially: a configural invariance model, a metric invariance model, a scalar invariance model, and a strict invariance model. In the configural model, (i.e., identical form), the parameters are all freely estimated across groups. In the metric model (i.e. weak or partial invariance), the parameters are constrained to be identical across groups. In the scalar model or "strong invariance," variables and paths variances are set to be equal across groups. Lastly, the strict model "strict invariance" additionally constrains the residuals to be the same across the three groups.

\section{Results}

\subsection{Descriptive Results}

We calculated probable clinical PTSD using the DSM-IV-TR criteria (APA, 2000), whereby probable PTSD assigned upon endorsing one re-experiencing symptom, three avoidance symptoms, and two hyperarousal symptoms. According to this formula, $32.2 \%$ met the criteria for PTSD. For EAA (existential annihilation anxiety), $22 \%$ scored 10 or higher, which indicates the presence of at least one type of such concern about existence. For depression, $69.4 \%$ scored 16 or above, which is the cutoff score that is commonly used to indicate the need for further assessment of the presence of major depressive disorder (e.g., Radloff, 1977). These high rates of potential PTSD and other symptoms are expected in a college students population that was going through the political turmoil of post-Arab Spring. Table 2 includes means, standard deviation, skewness and kurtosis of main variables. 
Table 2. Mean, standard deviation, skewness and kurtosis of selected main variables.

\begin{tabular}{ccccc}
\hline Variable & Mean & SD & $\begin{array}{c}\text { Skewness } \\
\text { statistic }^{\mathrm{a}}\end{array}$ & $\begin{array}{c}\text { Kurtosis } \\
\text { statistic }^{\mathrm{b}}\end{array}$ \\
\hline PTSD (CAPS 2) & 26.50 & 18.53 & .730 & -.031 \\
Existential Annihilation Anxiety & 8.24 & 2.85 & .020 & -.394 \\
Depression (CES-D) & 24.54 & 12.73 & .358 & -.584 \\
Perfectionism-Standards & 38.78 & 6.85 & 1.760 & 21.062 \\
Perfectionism-Order & 23.03 & 4.58 & -1.344 & 1.983 \\
Perfectionism-Discrepancy & 57.06 & 12.84 & -.060 & .822 \\
Post-traumatic Growth (PTG) & 64.24 & 19.62 & -1.053 & 1.277 \\
Cumulative Trauma Disorders (CTD) & 23.00 & 11.39 & .494 & .021 \\
CTD-Suicidality & 2.15 & 3.16 & 1.631 & 1.821 \\
CTD-Dissociation/Psychosis & 3.92 & 2.99 & .562 & -.391 \\
CTD-Executive function deficits & 4.19 & 2.15 & -.094 & -.592 \\
CTD-Depression/Anxiety/Somatization & 6.37 & 2.78 & -.090 & -.229 \\
Cumulative Stressors and Traumas Types & 3.40 & 3.07 & 1.67 & 5.78 \\
\hline
\end{tabular}

${ }^{\mathrm{a}} \mathrm{SE}=.098 .{ }^{\mathrm{b}} \mathrm{SE}=.196$.

\subsection{Reliability of APS and Its Sub-Scale Scores}

The Standards subscale (4 items) has an alpha reliability of .59 (fair to poor), the Order scale ( 4 items) has an alpha reliability of .81 (good), and the Discrepancy scale (12 items) has an alpha reliability of .77 (adequate to good). We should note that the alpha coefficient for standards subscale was poor, and we should be cautious in interpreting this factor.

\subsection{Structural Validity}

Exploratory factor analysis. Principal axis factoring (PAF) with oblique rotations produced the same three original factors (the first factor is self-discrepancy, the second factor is order, and the third factor is standards). The correlations between the oblique factors (in PAF) were not substantial (between -.12 and .24); however, the correlation between the order and standards sub-scales was significant (.34). Items 5, 22, and 18 (items from the standards subscale) did not load significantly on any of the factors; thus, we deleted them and reanalyzed the data. The three factors accounted for $41.08 \%$ of the variance and exceeded the 95th percentile of eigenvalues of factors derived from random data using parallel analysis (O'Connor, 2000). The first factor loaded significantly on the items identified previously in the "discrepancy" subscale and accounted for $17.76 \%$ of the variance. The second factor loaded on the four items identified earlier in the "order" subscale and accounted for $15.70 \%$ of the variance. The third factor included five items identified previously in the "standards" subscale and accounted for $7.62 \%$ of the variance. Table 3 includes means, standard deviation, commonalities and the factor loadings of each factor. 
Table 3. Factor analysis of the perfectionism scale: item means, standard deviations, communalities and three-factor solution loadings.

\begin{tabular}{|c|c|c|c|c|c|c|}
\hline Item & Mean & $\mathrm{SD}$ & Communalities & $\mathrm{F} 1^{\mathrm{a}}$ & $\mathrm{F} 2^{\mathrm{a}}$ & $\mathrm{F}^{\mathrm{a}}$ \\
\hline $\begin{array}{l}\text { 13) I am never satisfied with my } \\
\text { accomplishments. }\end{array}$ & 4.48 & 2.07 & 391 & .607 & -.088 & -.049 \\
\hline $\begin{array}{l}\text { 21) I hardly ever feel that what I have } \\
\text { done is good enough. }\end{array}$ & 4.63 & 1.84 & .401 & .602 & .030 & .063 \\
\hline $\begin{array}{l}\text { 23) I often feel disappointed after } \\
\text { completing a task because I know I } \\
\text { could have done better. }\end{array}$ & 5.43 & 1.78 & .248 & .491 & -.039 & -.039 \\
\hline $\begin{array}{l}\text { 20) I am hardly ever satisfied with my } \\
\text { performance. }\end{array}$ & 4.44 & 3.18 & .191 & .484 & -.042 & .058 \\
\hline $\begin{array}{l}\text { 19) I am seldom able to meet my own } \\
\text { high standards of performance. }\end{array}$ & 4.54 & 1.64 & .314 & .482 & -.004 & -.054 \\
\hline $\begin{array}{l}\text { 11) Doing my best never seems to be } \\
\text { enough. }\end{array}$ & 4.74 & 1.87 & .297 & .479 & .016 & .159 \\
\hline $\begin{array}{l}\text { 16) My performance rarely measures up } \\
\text { to my standards. }\end{array}$ & 4.73 & 1.66 & .293 & .443 & .057 & -.170 \\
\hline $\begin{array}{l}\text { 6) My best just never seems to be good } \\
\text { enough for me. }\end{array}$ & 4.71 & 1.84 & .224 & .442 & --.080 & .118 \\
\hline $\begin{array}{l}\text { 3) I often feel frustrated because I cannot } \\
\text { meet my goals. }\end{array}$ & 5.07 & 1.89 & .338 & .433 & .177 & -.151 \\
\hline 9) I rarely live up to my high standards & 4.69 & 1.73 & .269 & .382 & .009 & -.218 \\
\hline $\begin{array}{l}\text { 17) I am not satisfied even when I know I } \\
\text { have done my best. }\end{array}$ & 3.78 & 3.16 & .460 & .377 & -.022 & .041 \\
\hline $\begin{array}{l}\text { 15) I often worry about not measuring up } \\
\text { to my own expectations }\end{array}$ & 5.80 & 1.35 & .291 & .358 & .233 & -.030 \\
\hline 4) Neatness is important to me. & 5.70 & 1.52 & .656 & -.064 & .829 & .025 \\
\hline $\begin{array}{l}\text { 10) I like to always be organized and } \\
\text { disciplined. }\end{array}$ & 5.80 & 1.45 & .696 & .016 & .816 & .081 \\
\hline 2) I am an orderly person. & 5.22 & 1.56 & .542 & -.061 & .665 & .047 \\
\hline $\begin{array}{l}\text { 7) I think things should be put away in } \\
\text { their place }\end{array}$ & 6.30 & 1.17 & .309 & .052 & .513 & .103 \\
\hline 8) I have high expectations for myself. & 5.28 & 1.57 & .451 & -.064 & .017 & .711 \\
\hline 14) I expect the best from myself. & 5.85 & 1.36 & .400 & -.046 & .041 & .509 \\
\hline 12) I set very high standards for myself. & 5.12 & 1.62 & .259 & .129 & .054 & .440 \\
\hline $\begin{array}{l}\text { 1) I have high standards for my } \\
\text { performance at work or at school. }\end{array}$ & 5.16 & 1.38 & .239 & -.027 & .256 & .378 \\
\hline Eigenvalues & & & & 3.55 & 3.14 & 1.52 \\
\hline$\%$ of variance accounted for & & & & 17.76 & 15.70 & 7.62 \\
\hline
\end{tabular}

\subsection{Confirmatory Factor Analysis}

Confirmatory factor analysis was conducted on the second sub-sample $(\mathrm{N}=310)$ to test the model fit of the three factors. The model had a partial to poor fit. (It fit well using the RMSEA criterion, but it had a poor fit using the CFI criterion.) Modifying the three-factor model (correlating errors between items 6 and 11 and between items 7 and 9 and deleting items 18 and 22 and 5) did not improve the 
CFI. (Fit indices for the three-factor model after modifications: chi-square = 346.871, d.f. $=147, \mathrm{p}=.000, \mathrm{CFI}=.860$, RMSEA $=.066)$. Alternatively, when we set aside discrepancy and separately tested the two striving factors, order and standards, the two perfectionism-striving factors fit well without modifications (chi-square $=51.135$, d.f. $=19, p=.000, \mathrm{CFI}=.951$, RMSEA $=.074)$. The single "order" factor fit well without modification (chi-square $=2.048$, d.f. $=1, p$ $=.152$, CFI $=.999$, RMSEA $=.041)$, as did the a separate single standards factor (Chi-square $=6.496$, d.f. $=4, p=.165$, CFI $=.992$, RMSEA $=.032$ ). The single separate discrepancy factor fitted well with some modifications. The discrepancy single-factor modifications included correlating errors between items 3 and 15, between items 9 and 15 and between items 16 and 19 (chi-square $=116.248$, d.f. $=49, p=.000, \mathrm{CFI}=.943, \mathrm{RMSEA}=.047$, after modifications). It seems that striving for perfectionism's order and standards, and self-discrepancy would be better analyzed separately. Figure 1 and Figure 2 present the two main models with their fit statistics.

\subsection{Predictive Validity: Correlational and Path Analysis Results}

The results of zero-order correlation were straightforward. Order and standard subscales were negatively related to depression, existential anxiety (AA), PTSD, CTD, cumulative trauma, and different trauma types. The discrepancy subscale was positively associated with mental health variables cumulative trauma, and different trauma types. This is the first study that explores the relationship between perfectionism factors and trauma. Table 4 describes the results of the zero-order correlations. The results of the APS short version were similar.

Additionally, we conducted curve-estimation regression analysis to explore the non-linear relationships between the perfectionism main variables' scores as predictors of mental health. The standards score predicted significant cubic relationships $\left(R^{2}=.03, F=4.97<.002\right)$ with PTSD and significant quadratic $\left(R^{2}\right.$ $=.04, F=10.46<.001)$ and cubic relationships $\left(R^{2}=.04, F=9.43<.001\right)$ with depression. The non-linear cubic and quadratic models explained more variance than the linear models for these variables.

The discrepancy-subscale score predicted significant quadratic $\left(R^{2}=.08, F=\right.$ $27.26<.001)$ and cubic relationships $\left(R^{2}=.09, F=20.05<.001\right)$ with PTSD, significant cubic relationships $\left(R^{2}=.04, F=7.93<.001\right)$ with annihilation anxiety, and significant cubic relationships $\left(R^{2}=.15, F=34.98<.001\right)$ with depression. In analyses predicting CTD scales, the discrepancy score had significant cubic relationships $\left(R^{2}=.104, F=23.71<.001\right)$ with CTD-executive function deficits and self-control, significant cubic relationships $\left(R^{2}=.07, F=14.05<.001\right)$ with CTD-dissociation/psychosis, cubic relationships (r square $=.10, F=23.45$ $<.001)$ with CTD-suicidality, and significant quadratic $\left(R^{2}=.16, F=59.08\right.$ $<.001)$ and the CTD cumulative score $\left(R^{2}=.18, F=43.06<.001\right)$. The non-linear cubic and quadratic models explained more variance than the linear model for these variables. 


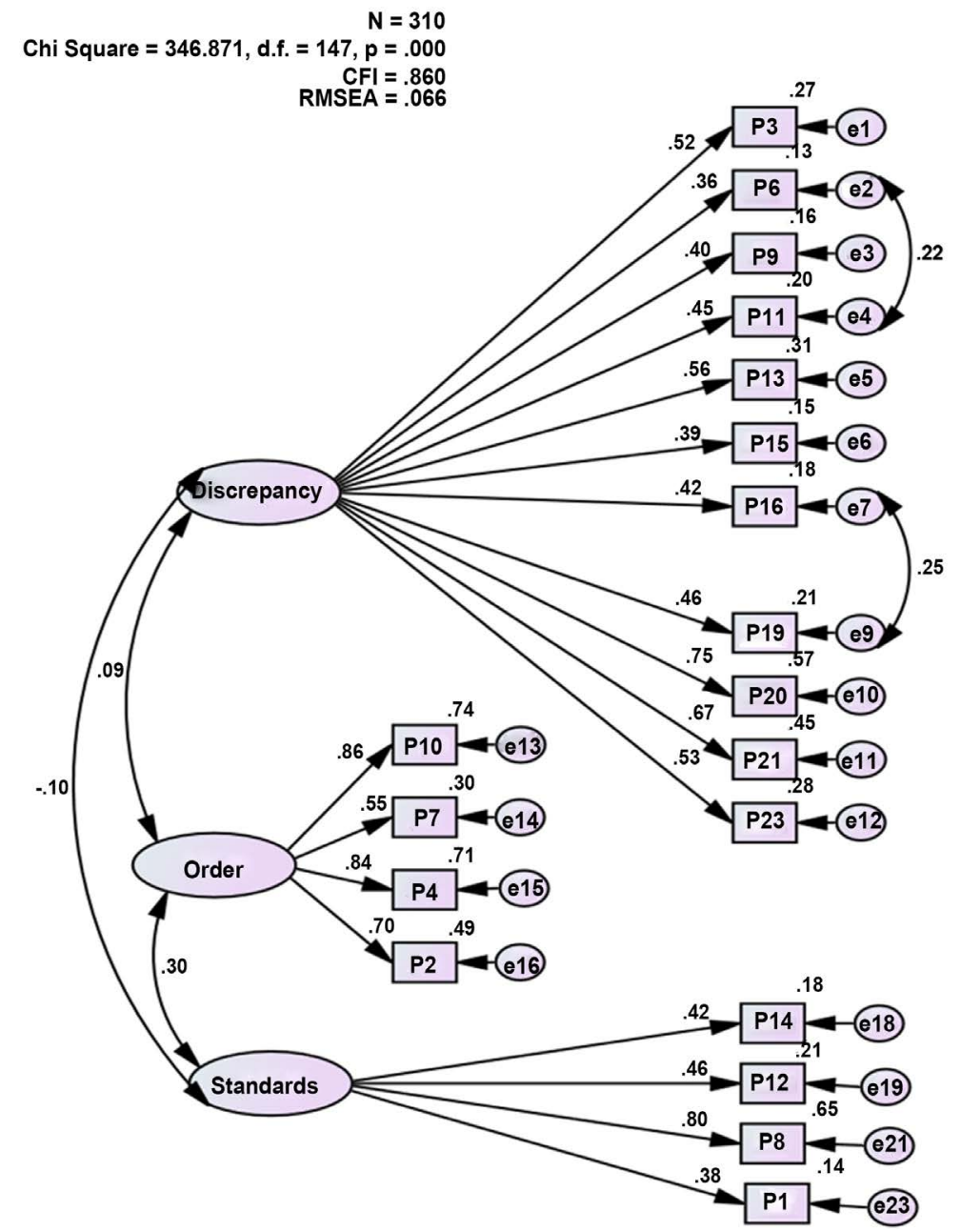

Figure 1. Confirmatory factor analysis: The three-factor model of perfectionism (Standards, Order, and Discrepancy), and the fit indices of the model.

\subsection{Multigroup Invariance Results}

In the Arabic (Egyptian) version, the three factor model, even it does not have a perfect fit with the data using CFI criteria, was strongly (not strictly) invariant across genders. The separate discrepancy, standards and orders subscales were also strongly invariant across genders. The two factors of standards and order model (that fitted the data well) was strictly invariant across genders.

We conducted Multigroup invariance to compare the Arabic adapted scale with the original English scale in an English sample of college students. We further compared between genders in the combined group. The three factors (discrepancy, order, and standards), and the two factors (standards and order) models had partial invariance across the English and Arabic groups, although they had strong invariance between genders in the combined English and Arabic group. The order subscale was partially invariant across groups but strictly invariant between genders in the combined group. The discrepancy and standards subscales were partially invariant across groups but strongly (not strictly) invariant between genders in the combined group. 

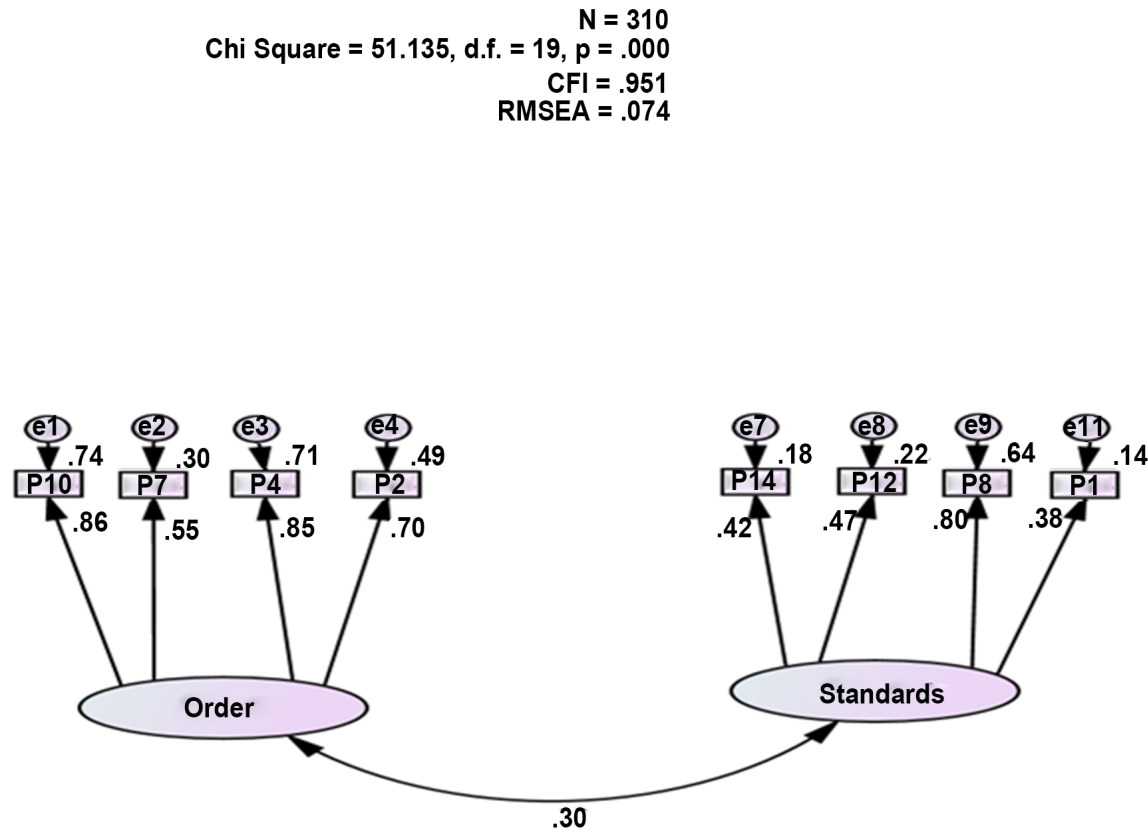

Figure 2. Confirmatory factor analysis: The two-factor model of perfectionism (order and Standards) and the fit indices of the model.

Table 4. Zero-order correlations among perfectionism sub-scales, mental health, and ptg variables.

\begin{tabular}{|c|c|c|c|}
\hline & Standards & Order & Discrepancy \\
\hline PTSD Scale (CAPS-2) & $-.07+$ & $-.11^{\star *}$ & $.28^{* * *}$ \\
\hline CTD Scale & $-.11^{* *}$ & -.04 & $.39^{* * *}$ \\
\hline CTD-Depression/Anxiety/Somatization & $-.09^{*}$ & .03 & $.33^{* * *}$ \\
\hline CTD-Executive Function Deficits & $-.10^{* *}$ & $-.10^{* *}$ & $.29^{* * *}$ \\
\hline CTD-Dissociation/Psychosis & $-.11^{* *}$ & -.031 & $.24^{\star * *}$ \\
\hline CTD-Suicidality & $-.08+$ & .01 & $.30^{* * *}$ \\
\hline PTSD Re-experiencing & -.06 & $-.07+$ & $.26^{\star * *}$ \\
\hline PTSD Avoidance & -.05 & $-.09^{*}$ & $.25^{* * *}$ \\
\hline PTSD Arousal & $-.07+$ & -.04 & $.22^{* * *}$ \\
\hline PTSD Dissociation & -.06 & $-.21^{* * *}$ & $.22^{* * *}$ \\
\hline Self-reported Poor Health & $-.10^{* *}$ & $-.10^{* *}$ & $.15^{* * *}$ \\
\hline AA-Existential Anxiety & $-.08^{\star}$ & .00 & $.18^{* *}$ \\
\hline CES-D Depression Scale & $-.10^{*}$ & $-.14^{* *}$ & $.35^{* *}$ \\
\hline Cumulative Stress and Trauma & $-.09^{\star}$ & $-.18^{* * *}$ & $.11^{\star *}$ \\
\hline Personal Identity Trauma & -.01 & -.05 & $.11^{\star *}$ \\
\hline Collective Identity Trauma & -.03 & $-.10^{* *}$ & .03 \\
\hline Attachment Trauma & $-.13^{* * *}$ & $-.13^{* * *}$ & .01 \\
\hline Role Identity Trauma & -.01 & $-.11^{\star *}$ & $.09^{*}$ \\
\hline Secondary Trauma & -.02 & $-.09^{*}$ & -.03 \\
\hline
\end{tabular}

$+p<.10 .{ }^{*} p<.05 .{ }^{* *} p<.01 .{ }^{* *} p<.001$. 
We further compared the Arabic adapted short version of the scale (Rice, Richardson, \& Tueller, 2014) with its original English version in an American English sample. For the adapted Arabic version and the keys for sub-scales and for the short version see Appendix. The two factors model (standards and discrepancy) of the short version was partially invariant across groups but strongly invariant across genders in the combined group. Similarly, the standards and discrepancy subscales of the short version were partially invariant across groups but strongly invariant across genders in the combined group. The results of Multigroup invariance are included in Table 5.

\section{Conclusion and Discussion}

APS-R scales largely seem to have adequate to fair psychometrics, except the standards sub-scale, which has poor reliability in this sample. The results indicated that although the measure's sub-scales scores may have adequate structural and predictive validity on their own, the measure as a whole should be looked at as an inventory with two or three different independent measures. The same can be said for the short version of the measure.

One of the contributions of the current study is expanding the predictive validity of the perfectionism striving and self-discrepancy to increased vulnerability to PTSD, complex PTSD, and AA, and its relationship to trauma. Its relationship to trauma never been explored before, and its relationship with PTSD is rarely explored. Striving and self-discrepancy, an internal dynamics related to the meaning-making process, found to contribute differentially to the initiation or suppression or vulnerability to PTSD, and complex PTSD as well as with EAA, as well as to posttraumatic growth (Shuwiekh, Kira, \& Ashby, 2017; Kira, Abou-Mediane et al., 2013).

Self-discrepancy (Higgins, 1987), as opposed to self-coherence/self-consistency is a pivotal mechanism in perfectionism and mental health and is at the root of the work of moral injury (Litz et al., 2009). Self-verification/self-affirmation and awareness of self-congruence (or self-discrepancy), which is a self-monitoring adaptive process, was found to be related to a variety of healthy personality characteristics (e.g., Swann, 2011). Self-threatening inconsistencies undermine the standing of perceived integrity, authenticity and adequacy of the self. They destabilize the maintenance of the person's positive self-image and self-evaluation (self-esteem and self-efficacy/adequacy) as adaptively and morally adequate. They question the person as competent, good, coherent, unitary, stable, and capable of controlling important outcomes (e.g., Steele, 1988). Self-discrepancy is implicated as a threat to the person's self-regard that may cause the moral injury and reduced self-esteem and efficacy, which all are important keys for mental health and wellbeing.

Another contribution of the current study is its probing of the non-linear relationships among perfectionism striving, self-discrepancy, and other dependent variables. The relationships among APS-R sub-scales and mental health seem 
Table 5. Multigroup invariance of different models of perfectionism scale and its short form between genders in the Egyptian sample and the combined sample, and between English and Arabic samples.

\begin{tabular}{|c|c|c|c|c|c|c|c|}
\hline \multicolumn{8}{|c|}{ Invariance of the two factors of standards and order between genders in the Egyptian Sample } \\
\hline & chi-square & $d f$ & $p$ & chi-square/df & $C F I$ & RMSEA & IFI \\
\hline Configural (structure) & 103.948 & 38 & .000 & 2.735 & .949 & .053 & .950 \\
\hline Metric (weights), & 120.534 & 44 & .000 & 2.739 & .941 & .053 & .942 \\
\hline Scalar (intercepts) & 169.679 & 52 & .000 & 3.263 & .939 & .061 & .940 \\
\hline Strict invariance & 204.149 & 63 & .000 & 3.240 & .891 & .060 & .891 \\
\hline \multicolumn{8}{|c|}{ Invariance analysis between genders for the standards subscale in the Egyptian Sample } \\
\hline & chi-square & $d f$ & $p$ & chi-square/df & $C F I$ & RMSEA & IFI \\
\hline Configural (structure) & 16.167 & 8 & .040 & 2.021 & .976 & .041 & .977 \\
\hline Metric (weights), & 29.289 & 12 & .004 & 2.441 & .969 & .048 & .966 \\
\hline Scalar (intercepts) & 40.715 & 17 & .001 & 2.395 & .960 & .048 & .951 \\
\hline Strict invariance & 486.211 & 24 & .000 & 20.259 & .000 & .177 & -.381 \\
\hline \multicolumn{8}{|c|}{ Invariance between the English and Arabic samples in the three-factor model } \\
\hline & chi-square & $d f$ & $p$ & chi-square/df & $C F I$ & RMSEA & $I F I$ \\
\hline Configural (unconstrained) & 988.723 & 324 & .000 & 3.052 & .934 & .042 & .934 \\
\hline Metric (weights), & 1125.998 & 341 & .000 & 3.302 & .926 & .046 & .922 \\
\hline Scalar (intercepts) & 1954.692 & 361 & .000 & 5.415 & .841 & .056 & .841 \\
\hline Strict invariance & 4323.594 & 392 & .000 & 11.030 & .607 & .092 & .606 \\
\hline \multicolumn{8}{|c|}{ Invariance of the three-factor model between genders in the combined English and Arabic samples } \\
\hline & chi-square & $d f$ & $p$ & chi-square/df & $C F I$ & RMSEA & $I F I$ \\
\hline Configural (unconstrained) & 993.407 & 318 & .000 & 3.124 & .926 & .043 & .927 \\
\hline Metric (weights), & 1017.817 & 335 & .000 & 3.038 & .926 & .042 & .926 \\
\hline Scalar (intercepts) & 1096.417 & 355 & .000 & 3.088 & .919 & .043 & .919 \\
\hline Strict invariance & 1693.482 & 389 & .000 & 4.353 & .858 & .054 & .858 \\
\hline \multicolumn{8}{|c|}{ Invariance of the three-factor model between genders in the combined English/Arabic sample } \\
\hline & chi-square & $d f$ & $p$ & chi-square/df & $C F I$ & RMSEA & $I F I$ \\
\hline Configural (unconstrained) & 993.407 & 318 & .000 & 3.124 & .926 & .043 & .927 \\
\hline Metric (weights), & 1017.817 & 335 & .000 & 3.038 & .926 & .042 & .926 \\
\hline Scalar (intercepts) & 1096.417 & 355 & .000 & 3.088 & .919 & .043 & .919 \\
\hline Strict invariance & 1693.482 & 389 & .000 & 4.353 & .858 & .054 & .858 \\
\hline \multicolumn{8}{|c|}{$\begin{array}{l}\text { Invariance of the two-factor model (Standards and Order) between genders in the combined } \\
\text { English and Arabic samples }\end{array}$} \\
\hline & chi-square & $d f$ & $p$ & chi-square/df & $C F I$ & RMSEA & $I F I$ \\
\hline Configural (unconstrained) & 243.496 & 52 & .000 & 4.683 & .953 & .056 & .953 \\
\hline Metric (weights), & 259.292 & 59 & .000 & 4.395 & .951 & .054 & .951 \\
\hline Scalar (intercepts) & 308.799 & 68 & .000 & 4.541 & .941 & .055 & .941 \\
\hline Strict invariance & 783.799 & 80 & .000 & 9.797 & .827 & .087 & .827 \\
\hline
\end{tabular}


Continued

\begin{tabular}{cccccccccc}
\hline \multicolumn{6}{c}{ Invariance of the short form two factors scale between genders in the Combined Sample } \\
\hline & chi-square & $d f$ & $p$ & chi-square/df & CFI & RMSEA & IFI \\
\hline Configural (structure) & 161.016 & 38 & .000 & 4.237 & .944 & .053 & .945 \\
Metric (weights), & 176.921 & 44 & .000 & 4.021 & .940 & .051 & .940 \\
Scalar (intercepts) & 221.781 & 52 & .000 & 4.265 & .934 & .053 & .933 \\
Strict invariance & 944.335 & 63 & .000 & 14.989 & .602 & .110 & .601 \\
\hline
\end{tabular}

primarily non-linear, which indicates that extreme and low striving (standards and order) do not have the positive effects found in intermediate striving. The same may apply to the negative effects of self-discrepancy. The linear analysis may reflect the intermediate ranges of striving and discrepancy.

The previous trend in perfectionism studies was to focus on striving for standards as the central component of healthy perfectionism. In some studies, the "order" is seen as a peripheral dimension and is thus dropped (e.g., Rice, Richardson, \& Tueller, 2014). In the current analysis, striving for order and self-control emerged as the strongest salient and positively substantial component of striving for self-perfection, compared to striving for standards. Further analysis showed that females strive more for order than males while males strive for standards more. Future studies may focus more on the further development and measurement of the striving for self-order and self-control component of perfectionism.

The results of Multigroup invariance highlighted the measure sub-scales strong invariance across genders in the Arabic version and across genders in the English and Arabic groups. However, all 3 subscales failed strong invariance with the English version; it simply means that you can't compare factor means between the groups. Comparisons based on correlations and regressions would be fine. The same findings obtained for the Arabic short version of the scale. However, the two samples (the Arabic and English) differ significantly in age, gender composition, and in some other demographics, which may have contributed to such lack of strong invariance.

\section{Limitations and Future Directions}

One of the limitations of the current study is that it used a sample of college students, which may be a good sample to measure such a complex structure and to compare results with previous studies that mostly used college students' samples; however, such samples may involve limited and biased representation. We recommend more studies using probability community and clinical samples.

Another limitation of the study was that we used measures that utilize participants' self-reports, which could be subject to under- or over-reporting of events due to current symptoms, embarrassment, shame, or social desirability. Also, the study used a cross-sectional design, and as a result, only probabilistic relationships can be drawn from the results.

Furthermore, caution should be exercised in interpreting the results of the 
standards subscale because its reliability was relatively low. Apart from the self-discrepancy subscale, which has high $R^{2}$ effect sizes in curve estimation regression, caution should be exercised in interpreting some results of the curve estimation for other sub-scales that accounted for less than $4 \%$ of the variance. With lower $R^{2}$ effect sizes, though statistically significant, its clinical or conceptual significance may be questioned (e.g., Ferguson, 2009).

Despite these limitations, the current results provided evidence of an adequate psychometrics of the Arabic version and gave us new insight into the structure and dynamics of perfectionism. It is important to leverage the current results for the future development of the APS-R measure and similar measures of perfectionism.

\section{References}

Ashby, J. S., \& Rice, K. G. (2002). Perfectionism, Dysfunctional Attitudes and Self-Esteem: A Structural Equations Analysis. Journal of Counseling and Development, 80, 197-203. https://doi.org/10.1002/j.1556-6678.2002.tb00183.x

Aydin, K. (2013). Cross-Cultural Validity of the Almost Perfect Scale-Revised on the College Students in the United States and Turkey. Educational Research and Reviews, 8 , $1150-1157$.

Baumeister, R. F., \& Vohs, K. D. (2002). The Pursuit of Meaningfulness in Life. In C. R. Snyder, \& S. J. Lopez (Eds.), Handbook of Positive Psychology (pp. 608-618). New York, NY: Oxford University Press.

Betemps, E. J., Smith, R. M., Baker, D. G., \& Rounds-Kugler, B. A. (2003). Measurement Precision of the Clinician-Administered PTSD Scale (CAPS): A RASCH Model Analysis. Journal of Applied Measurement, 4, 59-69.

Byrne, B. M. (2012). Structural Equation Modeling with Mplus: Basic Concepts, Applications, and Programming. New York, NY: Routledge Academic.

Cattell, R. B. (1966). The Scree Test for the Number of Factors. Multivariate Behavioral Research, 1, 245-276. https://doi.org/10.1207/s15327906mbr0102_10

Costello, A. B., \& Osborne, J. W. (2005). Best Practices in Exploratory Factor Analysis: Four Recommendations for Getting the Most from Your Analysis. Practical Assessment, Research \& Evaluation, 10, 2-9. http://pareonline.net/pdf/v10n7.pdf

Dunkley, D. M., Zuroff, D. C., \& Blankstein, K. R. (2003). Self-Critical Perfectionism and Daily Affect: Dispositional and Situational Influences on Stress and Coping. Journal of Personality and Social Psychology, 84, 234-252.

https://doi.org/10.1037/0022-3514.84.1.234

Egan, S. J., Hattaway, M., \& Kane, R. T. (2014). The Relationship between Perfectionism and Rumination in Post-Traumatic Stress Disorder. Behavioral and Cognitive Psychotherapy, 42, 211-223. https://doi.org/10.1017/S1352465812001129

Elhai, J. D., Lindsay, B. M., Gray, M. J., Grubaugh, A. L., North, T. C., \& Frueh, B. C. (2006). Examining the Uniqueness of Frequency and Intensity Symptom Ratings in Posttraumatic Stress Disorder Assessment. Journal of Nervous and Mental Disease, 194, 940-944. https://doi.org/10.1097/01.nmd.0000243011.76105.4b

Ferguson, C. J. (2009). An Effect Size Primer: A Guide for Clinicians and Researchers. Professional Psychology: Research and Practice, 40, 532-538.

https://doi.org/10.1037/a0015808 
Flett, G. L., \& Hewitt, P. L. (2002). Perfectionism and Maladjustment: An Overview of Theoretical, Definitional, and Treatment Issues. In G. L. Flett, \& P. L. Hewitt (Eds.), Perfectionism: Theory, Research, and Treatment (pp. 5-31). Washington DC: American Psychological Association. https://doi.org/10.1037/10458-001

Gillespie, G. L., \& Gates, D. M. (2013). Using Proactive Coping to Manage the Stress of Trauma Patient Care. Journal of Trauma Nursing, 20, 44-50. https://doi.org/10.1097/JTN.0b013e318286608e

Grzegorek, J. L., Slaney, R. B., Franze, S., \& Rice, K. G. (2004). Self-Criticism, Dependency, Self-Esteem and Grade Point Average Satisfaction among Clusters of Perfectionists and Non-Perfectionists. Journal of Counseling Psychology, 51, 192-200. https://doi.org/10.1037/0022-0167.51.2.192

Head, D., Singh, T., \& Bugg, J. M. (2012). The Moderating Role of Exercise on Stress-Related Effects on the Hippocampus and Memory in Later Adulthood. Neuropsychology, 26, 133-143. https://doi.org/10.1037/a0027108

Henson, R. K., \& Roberts, J. K. (2006). Use of Exploratory Analysis in Published Research: Common Errors and Some Comments on Improved Practice. Educational and Psychological Measurement, 66, 393-416. https://doi.org/10.1177/0013164405282485

Hewitt, P. L., \& Flett, G. L. (1991). Perfectionism in the Self and Social Contexts: Conceptualization, Assessment, and Association with Psychopathology. Journal of Personality and Social Psychology, 60, 456-470. https://doi.org/10.1037/0022-3514.60.3.456

Higgins, E. T. (1987). Self-Discrepancy: A Theory Relating Self and Affect. Psychological Review, 94, 319-340. https://doi.org/10.1037/0033-295X.94.3.319

International Test Commission (2010) ITC Guidelines for Translating and Adapting Tests: Version 2010. http://www.intestcom.org/upload/sitefiles/40.pdf

Kira, I. (2001). Taxonomy of Trauma and Trauma Assessment. Traumatology, 2, 73-86. https://doi.org/10.1177/153476560100700202

Kira, I. (2010). Etiology and Treatments of Post-Cumulative Traumatic Stress Disorders in Different Cultures. Traumatology: An International Journal, 16, 128-141. https://doi.org/10.1177/1534765610365914

Kira, I. A., Ashby, J. S., Odenat, L., \& Lewandowski, L. (2013). The Mental Health Effects of Torture Trauma and Its Severity: A Replication and Extension. Psychology, 4, 472-482.

Kira, I. A., Shuwiekh, H., Kucharska, J., Fawzi, M., Ashby, J. S., Omidy, A. Z., Abou-Mediene, S., \& Lewandowski, L. (2018). Trauma Proliferation and Stress Generation (TPSG) Dynamics and Their Implications for Clinical Science. American Journal of Orthopsychiatry.

Kira, I., Abou-Mediane, S., Ashby, J., Lewandowski, L., Mohanesh, J., \& Odenat, L. (2012). Post-Traumatic Growth Inventory: Psychometric Properties of the Arabic Version in Palestinian Adults. The International Journal of Educational and Psychological Assessment, 11, 120-137.

Kira, I., Abou-Mediane, S., Ashby, J., Odenat, L., Mohanesh, J., \& Alamia, H. (2013). The Dynamics of Post-Traumatic Growth across Different Trauma Types in a Palestinian Sample. Journal of Loss and Trauma: International Perspectives on Stress \& Coping, 18, 120-139. https://doi.org/10.1080/15325024.2012.679129

Kira, I., Ashby, J. S., Lewandowski, L., Alawneh, A. N., Mohanesh, J., \& Odenat, L. (2013). Advances in Continuous Traumatic Stress Theory: Traumatogenic Dynamics and Consequences of Intergroup Conflict: The Palestinian Adolescents Case. Psychology, 4, 396-409. https://doi.org/10.4236/psych.2013.44057 
Kira, I., Fawzi, M., \& Fawzi, M. (2013). The Dynamics of Cumulative Trauma and Trauma Types in Adults Patients with Psychiatric Disorders: Two Cross-Cultural Studies. Traumatology: An International Journal, 19, 179-195.

Kira, I., Lewandowski, L., Chiodo, L., \& Ibrahim, A. (2014). Advances in Systemic Trauma Theory: Traumatogenic Dynamics and Consequences of Backlash as a Multi-Systemic Trauma on Iraqi Refugee Muslim Adolescents. Psychology, 5, 389-412.

Kira, I., Lewandowski, L., Somers, C., Yoon, J., \& Chiodo, L. (2012). PTSD, Trauma Types, Cumulative Trauma, and IQ: The Case of African American and Iraqi Refugee Adolescents. Psychological Trauma: Theory, Research, Practice, and Policy, 4, 128-139. https://doi.org/10.1037/a0022121

Kira, I., Lewandowski, L., Templin, T., Ramaswamy, V., Ozkan, B., \& Mohanesh, J. (2008). Measuring Cumulative Trauma Dose, Types and Profiles Using a Development-Based Taxonomy of Trauma. Traumatology: International Journal, 14, 62-87.

https://doi.org/10.1177/1534765608319324

Kira, I., Shuwiekh, H., \& Bujold-Bugeaud (2017). Toward Identifying the Etiologies of Gender Differences in Authoritarianism and Mental Health: An Egyptian Study. Peace and Conflict: Journal of Peace Psychology, 23, 183-188.

https://doi.org/10.1037/pac0000206

Kira, I., Shuwiekh, H., Kucharska, J., Abu-Ras, W., \& Bujold-Bugeaud, M. (2017). The Dynamics Underlying the Negative Mental Health Effects of Gender Discrimination in Two Samples: Poland and Egypt. Current Psychology, 1-15. https://doi.org/10.1007/s12144-017-9730-5

Kira, I., Smith, I., Lewandowski, L., \& Templin, T. (2010). The Effects of Perceived Gender Discrimination on Refugee Torture Survivors: A Cross-Cultural Traumatology Perspective. Journal of the American Psychiatric Nurses Association, 16, 299-306. https://doi.org/10.1177/1078390310384401

Kira, I., Templin, T., Lewandowski, L., \& Shuwiekh, H. (2018). A Conceptual Model and Measurement of Identity-Based, Existential Annihilation Anxieties (EAA). Psychology, 9, 1306-1328.

Kira, I., Templin, T., Lewandowski, L., Ashby, J. S., Oladele, A., \& Odenat, L. (2012). Cumulative Trauma Disorders Scale: Two Studies. Psychology, 3, 643-656. https://doi.org/10.4236/psych.2012.39099

Kira, I., Templin, T., Lewandowski, L., Ramaswamy, V., Bulent, O., Mohanesh, J., \& Abdulkhaleq, H. (2012). Collective and Personal Annihilation Anxiety: Measuring Annihilation Anxiety AA. Psychology, 3, 90-99. https://doi.org/10.4236/psych.2012.31015

Litz, B. T., Stein, N., Delaney, E., Lebowitz, L., Nash, W. P., Silva, C., \& Maguen, S. (2009). Moral Injury and Moral Repair in War Veterans: A Preliminary Model and Intervention Strategy. Clinical Psychology Review, 29, 695-706. https://doi.org/10.1016/j.cpr.2009.07.003

Millender, E. I. (2013). Cumulative Trauma among Adult Mayas Living in Southeast Florida. Boca Raton, FL: Florida Atlantic University.

Mobley, M., Slaney, R. B., \& Rice, K. G. (2005). Cultural Validity of the Almost Perfect Scale-Revised for African American College Students. Journal of Counseling Psychology, 52, 629-639. https://doi.org/10.1037/0022-0167.52.4.629

Moretz, M. W., \& McKay, D. (2009). The Role of Perfectionism in Obsessive-Compulsive Symptoms: "Not Just Right" Experiences and Checking Compulsions. Journal of Anxiety Disorders, 23, 640-644. https://doi.org/10.1016/j.janxdis.2009.01.015

O'Connor, B. P. (2000). SPSS and SAS Programs for Determining the Number of Components Using Parallel Analysis and Velicer's MAP Test. Behavior Research Methods, 
Instruments, \& Computers, 32, 396-402. https://doi.org/10.3758/BF03200807

Omidy Nael, A. Z. O. (2012). The Influence of Cumulative Trauma, Binge Eating, and Coping Styles on the General Health of American Indians. Stillwater, OK: Oklahoma State University.

Park, C., \& Folkman, S. (1997). Meaning in the Context of Stress and Coping. Review of General Psychiatry, 1, 115-144. https://doi.org/10.1037/1089-2680.1.2.115

Radloff, L. S. (1977). The CES-D Scale: A Self-Report Depression Scale for Research in the General Population. Applied Psychological Measurement, 1, 385-401. https://doi.org/10.1177/014662167700100306

Rice, K. G., Richardson, C. M. E., \& Tueller, S. (2014). The Short Form of the Revised Almost Perfect Scale. Journal of Personality Assessment, 96, 368-379. https://doi.org/10.1080/00223891.2013.838172

Saboonchi, F., \& Lundh, L. G. (1997). Perfectionism, Self-Consciousness, and Anxiety. Personality and Individual Differences, 22, 921-928. https://doi.org/10.1016/S0191-8869(96)00274-7

Slaney, R. B., Chadha, N., Mobley, M., \& Kennedy, S. (2000). Perfectionism in Asian Indians: Exploring the Meaning of the Construct in India. Counseling Psychologist, 28, 10-31. https://doi.org/10.1177/0011000000281002

Slaney, R. B., Rice, K. G., Mobley, M., Trippi, J., \& Ashby, J. S. (2001). The Almost Perfect Scale-Revised. Measurement and Evaluation in Counseling and Development, 34, 130-145.

Steele, C. M. (1988). The Psychology of Self-Affirmation: Sustaining the Integrity of the Self. In Advances in Experimental Social Psychology (Vol. 21, pp. 261-302). Cambridge, MA: Academic Press.

Stoeber, J., \& Otto, K. (2006). Positive Conceptions of Perfectionism: Approaches, Evidence, Challenges. Personality and Social Psychology Review, 10, 295-319. https://doi.org/10.1207/s15327957pspr1004_2

Swann Jr., W. B. (2011). Self-Verification Theory. In P. A. M. Van Lange, A. W. Kruglanski, \& E. T. Higgins (Eds.), Handbook of Theories of Social Psychology (Vol. 2, pp. 23-42). Thousand Oaks, CA: SAGE Publications.

Ulu, I. P. (2007). An Investigation of Adaptive and Maladaptive Dimensions of Perfectionism in Relation to Adult Attachment and Big Five Personality Traits. Unpublished Doctoral Dissertation, Ankara: Middle East Technical University.

Ulu, I. P., Tezer, E., \& Slaney, R. B. (2012). Investigation of Adaptive and Maladaptive Perfectionism with Turkish Almost Perfect Scale-Revised. Psychological Reports, 110, 1007-1020. https://doi.org/10.2466/09.02.20.PR0.110.3.1007-1020

Wang, K. T., Puri, R., Slaney, R. B., Methikalam, B., \& Chadha, N. (2012). Cultural Validity of Perfectionism among Indian Students: Examining Personal and Family Aspects through a Collectivistic Perspective. Measurement and Evaluation in Counseling and Development, 45, 32-48. https://doi.org/10.1177/0748175611423109

Wang, K. T., Slaney, R. B., \& Rice, K. G. (2007). Perfectionism in Chinese University Students from Taiwan: A Study of Psychological Well-Being and Achievement Motivation. Personality and Individual Differences, 42, 1279-1290. https://doi.org/10.1016/j.paid.2006.10.006

Wang, K. T., Yuen, M., \& Slaney, R. B. (2009). Perfectionism, Depression, Loneliness, and Life Satisfaction: A Study of High School Students in Hong Kong. The Counseling Psychologist, 37, 249-274. https://doi.org/10.1177/0011000008315975

Weathers, F., Keane, T., \& Davidson, J. (2001). The Clinician-Administered PTSD Scale: 
A Review of the First Ten Years of Research. Depression and Anxiety, 13, 132-156. https://doi.org/10.1002/da.1029

Yang, L., Liang, B. Y., Zhang, X. G., \& Wu, Y. C. (2007). The Chinese Version of the Almost Perfect Scale-Revised. Acta Phytotaxonomica Sinica, 5, 139-144. 
Appendix: The Arabic Version of Perfectionism Scale

فيما يلي مجموعة من العبارات التي تصف اتجاهات الأفراد نحو أنفسهم، وأدائهم، والآخرين. لا توجد إجابة صحيحة وأخرى والخ خاطئة.

برجاء الإجابة على كل البنود مستخدمًا انطباعك الأول، ولا تستهلك وقتًا كثيرًا في الإجابة على البنود.

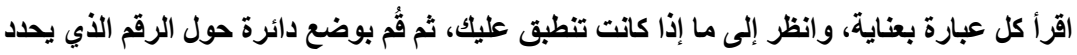
مدى انطباق العبارة عليك.
(7)
(6)
(5)
(4)
(3)
(2)
(1)

لا أوافق بقوة لا أوافق لا أوافق إلى حد ما محايد أوافق إلى حد ما أوافق أوافق بقوة

\begin{tabular}{|c|c|c|c|c|c|c|c|c|}
\hline 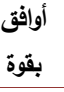 & أوافق & أوافق إلى ما & 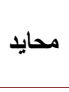 & 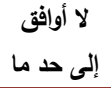 & 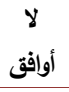 & لا بقوة & 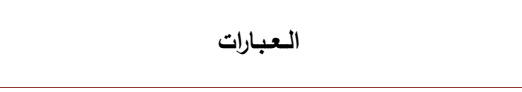 & b \\
\hline 7 & 6 & 5 & 4 & 3 & 2 & 1 & لدي معايير مرتفعة لأدائي في العمل أو المدرسة. & 1 \\
\hline 7 & 6 & 5 & 4 & 3 & 2 & 1 & 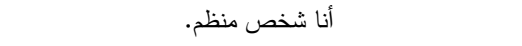 & 2 \\
\hline 7 & 6 & 5 & 4 & 3 & 2 & 1 & أشعر كثيرًا بالإحباط لعدم اسنطاعتي تحقيق أهدافي. & 3 \\
\hline 7 & 6 & 5 & 4 & 3 & 2 & 1 & النظافة ضرورية جداً بالنسبة لي. & 4 \\
\hline 7 & 6 & 5 & 4 & 3 & 2 & 1 & إذا لم تتوقع الكثير من نفسك، لن تتجح أبدًا. & 5 \\
\hline 7 & 6 & 5 & 4 & 3 & 2 & 1 & أفضل جهد مبذول لدي لا يبدو مكافئ جيد بالنسبة لي. & 6 \\
\hline 7 & 6 & 5 & 4 & 3 & 2 & 1 & أعتقد أنه يجب وضع الأشياء بعيدة عن أماكنها. & 7 \\
\hline 7 & 6 & 5 & 4 & 3 & 2 & 1 & لاي نوقعات عالية عن نفسي. & 8 \\
\hline 7 & 6 & 5 & 4 & 3 & 2 & 1 & نادرا ما أصل إلى مستوى معاييري العالية. & 9 \\
\hline 7 & 6 & 5 & 4 & 3 & 2 & 1 & أحب دائمًا أن أكون منظم ومنضبط. & 10 \\
\hline 7 & 6 & 5 & 4 & 3 & 2 & 1 & عمل الأفضل لدى لا يبدو كافٍ لي. & 11 \\
\hline 7 & 6 & 5 & 4 & 3 & 2 & 1 & وضعت لنفسي معايير عالية جدًا. & 12 \\
\hline 7 & 6 & 5 & 4 & 3 & 2 & 1 & لست راضيًا أبدًا على انجازاتي. & 13 \\
\hline 7 & 6 & 5 & 4 & 3 & 2 & 1 & 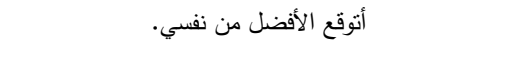 & 14 \\
\hline 7 & 6 & 5 & 4 & 3 & 2 & 1 & أقلق غالبًا من عدم وصولي إلى مسنوى توقعاتي المطلوبة. & 15 \\
\hline 7 & 6 & 5 & 4 & 3 & 2 & 1 & نادرًا ما يصل أدائي إلى مستوى معاييري المرتفعة. & 16 \\
\hline 7 & 6 & 5 & 4 & 3 & 2 & 1 & أنا غير راضي حتى لو علدت أني قد بذلت جهدي. & 17 \\
\hline 7 & 6 & 5 & 4 & 3 & 2 & 1 & أحاول أبذل قصارى جهدي في كل شيء أقوم به. & 18 \\
\hline 7 & 6 & 5 & 4 & 3 & 2 & 1 & نادرًا ما أستطيع الوصول إلى معاييري الخاصة عن أدائي. & 19 \\
\hline 7 & 6 & 5 & 4 & 3 & 2 & 1 & أجد صعوبة في الرضا عن أدائي. & 20 \\
\hline 7 & 6 & 5 & 4 & 3 & 2 & 1 & أجد صعوبة في الثعور بان ما فعلته جيد بما يكفي. & 21 \\
\hline 7 & 6 & 5 & 4 & 3 & 2 & 1 & ل لاى حافز قوي إلى السعي للتميز . & 22 \\
\hline 7 & 6 & 5 & 4 & 3 & 2 & 1 & كثيرًا ما أشعر بخيبة الأمل بعد انتهاء المهمة لمعرفتي بأنه & 23 \\
\hline
\end{tabular}

(Slaney, Mobley, Trippi, Ashby, \& Johnson, 1996).

\section{Keys: Original version}

Standards $=1 \cdot 5 \cdot 8 \cdot 12 \cdot 14 \cdot 18 \cdot 22$.

Order $=2 \cdot 4 \cdot 7 \cdot 10$.

Discrepancy $=3$ ، 6، 9، 11، 13، 15، 16، 17، 19، 20، 21، 23 .

Short Version (standards and Discrepancy only) 8, 11, 12, 14.16, 20, 22, 23

Standards: 8, 12, 14, 22

Discrepancy: 11, 16, 20, 23 